Etnográfica

Revista do Centro em Rede de Investigação em

Antropologia

vol. 23 (1) | 2019

Vol. 23 (1)

\title{
"It's a great place for kids!": the settlement of Ma'ale Adumim as a suburban safe space
}

"É um sítio ideal para as crianças!" o colonato de Ma'ale Adumim como espaço suburbano seguro

Marco Allegra

\section{(2) OpenEdition}

Journals

Electronic version

URL: https://journals.openedition.org/etnografica/6455

DOI: 10.4000/etnografica.6455

ISSN: 2182-2891

\section{Publisher}

Centro em Rede de Investigação em Antropologia

\section{Printed version}

Date of publication: 1 February 2019

Number of pages: 181-200

ISSN: 0873-6561

\section{Electronic reference}

Marco Allegra, "'It's a great place for kids!": the settlement of Ma'ale Adumim as a suburban safe space ", Etnográfica [Online], vol. 23 (1) | 2019, Online since 21 March 2019, connection on 20 January 2022. URL: http://journals.openedition.org/etnografica/6455 ; DOI: https://doi.org/10.4000/ etnografica. 6455

\section{(c) (;) (9)}

Etnográfica is licensed under a Creative Commons Attribution-NonCommercial 4.0 International License. 


\section{"It's a great place for kids!": the settlement of Ma'ale Adumim as a suburban safe space}

\section{Marco Allegra}

The status of Jerusalem is almost universally regarded as the single most divisive issue in Israeli-Palestinian relations; and Israel's settlement policy - and its territorial and demographic implications - is widely considered as the most significant "fact on the ground" established by Israel since 1967. We address these issues by observing how Israel's settlement policy in the area of metropolitan Jerusalem transformed the material, symbolic and political landscape of Israeli-Palestinian relations. Through the case study of the settlement of Ma'ale Adumim, this paper focuses on settlers' place attachment, personal geographies, and the relation between the latter and the production of space. We maintain that the "suburban experience" embodied in the lives of the residents illustrates the action of powerful drivers of the overall process of normalization of Jewish presence in the West Bank; in turn, this rendered the settlement policy relatively uncontroversial for large sectors of Israeli public opinion. Also, we maintain that settlements such as Ma'ale Adumim are also the product of the quest for a suburban "safe space" - i.e. an enclosed space designed to avoid contacts with "unpleasant otherness" that residents of the suburbs all over the world often associate to life in the inner city.

KEYWORDS: Jerusalem, Israeli settlements, Israeli-Palestinian conflict, West Bank, suburbs.

"É um sítio ideal para as crianças!" O colonato de Ma'ale Adumim como espaço suburbano seguro - O estatuto de Jerusalém é quase universalmente considerado a questão mais fraturante nas relações israelo-palestinianas; a política dos colonatos de Israel - e suas implicações territoriais e demográficas - é amplamente considerada como o "fact on the ground" mais significativo estabelecido por Israel desde 1967. Através do exame do estudo de caso do Ma'ale Adumim, abordaremos estas questões observando como a política dos colonatos na área metropolitana de Jerusalém transformou a paisagem material, simbólica e política das relações israelo-palestinianas. O artigo tratará as geografias pessoais dos colonos e a relação entre estas e a produção do espaço. A "experiência suburbana" da vida dos colonos permite-nos compreender os principais fatores do processo de normalização da presença judaica na Cisjordânia; ao mesmo tempo, este fenómeno tornou a política de fixação relativamente incontroversa para grandes sectores da opinião pública em Israel. Além disso, afirmamos que colonatos como Ma'ale Adumim também são o produto da busca de um "espaço (suburbano) seguro"- ou seja, um espaço fechado onde os residentes podem evitar contactos com "alteridades desagradáveis", associados à vida na inner city de Jerusalém. 
KEYWORDS: Jerusalém, colonatos israelitas, conflito israelo-palestiniano, Cisjordânia, subúrbios.

ALLEGRA, Marco (marco.allegra2010@gmail.com) - Instituto de Ciências Sociais, Universidade de Lisboa (ICS-ULisboa); ISCTE - Instituto Universitário de Lisboa, Centro de Investigação e Estudos de Sociologia (CIES-IUL), Portugal.

ISRAEL'S SETTLEMENT POLICY AND ITS WIDE-RANGING IMPLICATIONS have been subject to intense debate for decades. Their development has represented a source of friction between Israelis and Palestinians and has substantially changed the human geography of the West Bank. Conventional wisdom (and, to a certain extent, the scholarly literature on the subject), however, is often misleading; indeed, settlers are usually depicted as committed activists or messianic fanatics who have moved to the West Bank for religious or ideological reasons - and, ultimately, to redeem the land and claim it for Zionism and the Jewish people.

Still, this conventional wisdom - which is visually represented by the image of groups of bearded, armed settlers patrolling the hills of the West Bank hardly represents an accurate account of the reality of the settlements, and cannot fully explain the dynamics of their proliferation. As I have argued elsewhere (Allegra, Handel and Maggor 2017), the development of Israel's settlement policy can be understood only if we view it against the background of broader historical, political and socioeconomic trends that have defined Israel's and the region's history. This article, in particular, focuses on the relatively under-researched reality of suburban settlements (i.e. of large, non-ideological communities located at commuting distance from Israel's main urban centres) and, specifically, on the settlement of Ma'ale Adumim.

My argument is twofold. In the first place, I argue that the relative success of Israel's settlement policy, to a significant extent, is due to - and can be measured by - the banalization of Jewish presence in the West Bank. In other words, settlements have proliferated largely because ordinary Israelis can live perfectly ordinary lives in their communities; in turn, the banality of life in the settlements have greatly eased the incorporation of the West Bank into Israel's socioeconomic fabric. In the second place, I argue that the settlements are part and parcel of ongoing dynamics of socio-spatial segregation that are not exclusively premised on the Jews-Palestinians dichotomy, but concern the Israeli-Jewish society as well; in particular, suburban settlements like Ma'ale Adumim represent the perfect destinations for Israeli Jews that are looking for a suburban "safe space," an enclosed space designed to avoid 
contacts with "unpleased otherness" that residents associate to life in the inner city.

This article is based on a project of investigation on Israel's settlement policy, whose main focus has been the town of Ma'ale Adumim, a community of some 40,000 residents located in the eastern periphery of Jerusalem, and which has resulted in several publications (Allegra, 2013, 2014, 2016; Rokem and Allegra, 2016; Allegra, Handel and Maggor 2017). While not an ethnography by any standard, my research in Ma'ale Adumim involved several field visits over various years and aimed at building a comprehensive profile of the settlements encompassing history, planning and architectural issues, politico-strategic controversies and the daily life of residents. This article is mainly based on the interviews I conducted with some of the residents of the community (the names given in the text are fictitious). The first section presents some background information on the settlements. The second section introduces the main arguments of the article through the idea of "banality of colonization" - i. e. the idea that the settlements have proliferated largely because they are in many ways indistinguishable from other localities in Israel. The third section introduces the case study of Ma'ale Adumim as representative of the largely overlooked category of "suburban settlements." The fourth, larger section presents the empirical material on Ma'ale Adumim and argues that, in order to understand the proliferation of settlements, we need to consider them not only through the Israeli-Palestinian dichotomy, but also as "safe spaces" which offer their residents a suburban lifestyle and distance themselves from the negative externalities associated to life in the inner city. The last section offers some brief conclusive remarks.

\section{THE SETTLEMENTS}

Before going further, some terminological clarifications and background information are in order. The word "settlements" indicates here the 270-280 Jewish communities established by Israel in the West Bank and in the Golan Heights (and in Gaza, before their complete evacuation in 2005) after the 1967 Arab-Israeli war, irrespectively of their status in Israel's administrative system and international law; this definition includes what is commonly known as "East Jerusalem," an area of some 70 square kilometres that contains the medieval Old City of Jerusalem and constitutes the only part of the West Bank that has been formally annexed by Israel. Wherever used to identify specific territories, the terms "Israel" (or "Israel proper") and "West Bank" will refer to the pre1967 armistice lines between Israel and its neighbours - meaning that the West Bank, in the definition used here, includes East Jerusalem. The term "Israel/ Palestine" will refer to the whole area that is presently under Israeli control, which includes Israel proper, the West Bank, Gaza and the Golan Heights. 
Settlements, which considerably vary in nature and scale (from urban centres counting tens of thousands of residents, to single-building settlements), host today more than 600,000 residents (of which some two hundred thousand Jewish residents of East Jerusalem) out of a total Israeli population of some eight million (Allegra 2016). Major population centres (with a population of 10,000 residents or more) are the "new neighbourhoods" established in East Jerusalem (Gilo, Ramot Allon, Neve Ya'akov, Pisgat Ze'ev, Har Homa, Ramat Shlomo, and East Talpiot) and a few large communities in the West Bank (Modi'in Illit, Beitar Illit, Ma'ale Adumim, Ariel, and Giv'at Ze'ev), whose combined population amounted to 330,000 residents in 2011; at the same date, nine other settlements in the West Bank (Efrat, French Hill, Kiryat Arba, Alfei Menashe, Ramat Eshkol, Oranit, Karnei Shomron, Kochav Ya'akov, and Beit El) had a population between 5,000 and 10,000 units (B’Tselem 2018).

Administratively speaking, these communities are largely indistinguishable from other centres in Israel, although both local authorities and individual settlers enjoy a larger share of public funds than the Israeli average, in the form of tax discounts, direct government transfers, and infrastructural investments. While Israel has formally maintained the Jordanian legal system in the West Bank (with the abovementioned exception of East Jerusalem), it has also repeatedly amended Jordanian legislation through the enactment of hundreds of military orders. Technically, the settlements remain under the responsibility of Israel's military administration, but the military orders that apply to them have been modelled on Israeli laws, so that as Eyal Benvenisti (1989: preface) pointed out, since the end of the 1980s, "the pre-June 1967 borders have faded for almost all legal purposes that reflect Israeli interest." Parallel to the legal infrastructure, a physical infrastructure has been created over the years in the West Bank, which serves the settlements by connecting them to Israel's transportation network and main population centres.

Last but not least, the vast majority of settlers live in large suburban communities located near the Green Line (the pre-1967 border between Israel and Jordan) - in particular, between two-thirds and four-fifths live in the metropolitan area of Jerusalem, both inside the municipal boundaries of the city and in the so-called "settlement blocs" in its immediate periphery, namely the clusters around the communities of Ma'ale Adumim, Modi'in Illit, Giv'at Ze'ev, and the Gush Etzion (see Allegra 2016). These settlements, along with the Ariel bloc in the northern part of the West Bank, are often referred to as being inhabited by "quality-of-life settlers," Israelis that have moved to the West Bank in search of affordable housing, economic benefits, and, ultimately, upward social mobility. 


\section{THE BANALITY OF OCCUPATION}

The mention of "quality-of-life settlers" introduces my first broad argument about Israel's settlement policy: while most scholarly contributions have focused almost exclusively on the ideological and strategic drivers of the expansion of the settlements, I argue that settlements have proliferated largely because of the fact that they are relatively normal communities to live in, which are in many ways indistinguishable from other localities in Israel; in other words, that Israel's settlement policy has been successful precisely because of the relatively banal and mundane factors underlying it, which has in turn allowed for the entrenchment of Israeli control over the West Bank and the dramatic transformation of the landscape of Israel/Palestine as a whole.

In making this argument, I am certainly not implying that strategic and ideological concerns have not been important in the development of Israel's settlement policy; rather, I am suggesting that we should be sceptical of the kind of single-factor explanations that often underlie the studies that focus on the role of the settlers' movement and of its symbiosis with the Israeli state. The idea of "banality of the occupation" invites us to think about the settlements in a more holistic manner: the normalization of the settlements was not produced by one specific agent motivated by ideological concerns, but rather by pluralistic coalitions whose participants (politicians and activists, planners and bureaucrats, businessmen and settler-consumers) did not necessarily partake a common ideology, and were acting against the background of larger processes and trends which developed within the Israeli society (demographic and economic cycles, dynamics of welfare retrenchment, the changing political economy of industry and employment, and so forth).

The literature on Israel's settlement policy has often assumed the history of national-religious Gush Emunim (the "Bloc of the Faithful," a movement founded in 1973 that conducted aggressive political campaigns for the "redemption" of the land) as a paradigm of the settlement policy as a whole (Feige 2009); indeed, the scholarly study of the settlements has been by and large the study of the organization, the political culture and the agency of the Gush Emunim and its likes (Newman 1985; Lustick 1988; Aran 1991; Sprinzak 1991; Friedman 1992). Many studies in the last decade or so (Peled and Shafir 2002; Gorenberg 2006; Eldar and Zertal 2007; Ranta 2009) have explicitly or implicitly criticized the previous literature for its excessive emphasis on the role of the national-religious movement, which, as Yehuda Shenhav argued, has framed the proliferation of the settlements as a "spontaneous and random undertaking by eccentrics" (Shenhav 2012: 31), and as a process in which the Israeli state has been drawn against its will or best interest. These contributions have emphasized the role of the state in developing 
and supporting the expansion of the settlements; however, they have hardly challenged the prevailing consensus on the role of the settlers' movement, or explored lines of enquiry that did not focus on the strategic and ethnonational imperatives behind the establishment of the settlements.

It is not by chance that, throughout this literature, the foundation of the first Gush Emunim settlements (and in particular of the "capital" of the movement, the community of Ofra) has assumed a paradigmatic value. As the Israeli journalist Ari Shavit tells us in his bestseller, My Promised Land: The Triumph and Tragedy of Israel,

"The nightmare we [the members of Peace Now during the 1980s] envisioned turned into reality. That is why some thirty years later, I am driving to Ofra - the mother of all settlements - not to fight it, but to understand it. To understand how the settlements turned from rightist fantasy to historical fact" (Shavit 2013: 203, our emphasis).

For Shavit and many others, understanding the settlements means understanding Ofra; I would argue instead that Ma'ale Adumim offers a better case study in this respect.

In the first place, Ofra was not the "mother of all settlements." Not only at the time of Ofra's foundation several other settlements had already been established but, more importantly, it would be difficult to understand the variety of settlement patterns (in terms of genesis, location, socioeconomic fabric, and so forth) and explain the overall development of Israel's settlement policy by looking to Ofra - a community established in a relatively peripheral location of the West Bank and inhabited by some 3,000 residents, most of which share the national-religious ideology of the Gush Emunim. As we have noted, most of the settlers' population is constituted, rather than by settlers-activists, by settlers-commuters that live in large, fully-serviced communities located near the main Israeli employment centres.

In the second place, the reference to Ofra reflects the overemphasis on the agency of the Gush Emunim. Settlements are not a "rightist fantasy" that the settlers' movement has imposed on the otherwise sane and rational body of the Israeli nation. Indeed, many recent contributions have pointed out how the settlers have always enjoyed the support of powerful allies in the Israeli establishment, both on the right and the left (Gorenberg 2006; Eldar and Zertal 2007; Ranta 2009, 2015), and that the Gush Emunim itself has been successful, to a large extent, because it was able to latch on to some key trends developing in the Israeli society of the 1970s (Newman 2017). The success of the settlements depended on the convergence of different interests and rationalities, and, in a more operative sense, on the formation of broad coalitions of actors in support of a given project. 
In the third place, assuming Ofra, home to the aristocracy of the national-religious movement, as paradigm of Israel's settlement policy tends to corroborate the idea that the settlements are an enclosed community of religious fundamentalists, existing beyond the administrative, cultural and socio-political borders of Israel proper - for a critical assessment of this view, see Dalsheim and Harel (2009). As Adam LeBor has put it,

"[t]here are two Israels: one inside the Green Line, the 1967 border, the other an occupying power extending beyond it. The first is a vibrant democracy, with Arab members of Parliament, university professors and lawyers, beauty queens and soldiers, and even a Muslim cabinet minister [...] Across the Green Line, the West Bank, captured in 1967, is another country, neither Israel nor Palestine, but a lawless place, where the Jewish settler, rifle in one hand and prayer book in the other, is undisputed king" (LeBor 2007).

Against this stereotyped image of the settler-activist (and the continued reliance on the Green Line as a meaningful territorial artefact), several recent studies have pointed out how the population of the settlements tends to mirror Israel's social and cultural diversity. Needless to say, a substantial part of Israel's political, administrative, economic and cultural institutions are located "across the Green Line," including half of the country's capital and several bodies of local government, hundreds of schools and one of the nine Israeli universities, touristic sites and industrial areas, and so forth. The settlers' population includes religious and secular communities, recent immigrants and veteran Israelis, and a wide range of socioeconomic groups (Dalsheim 2008; Weiss 2011; Cahaner and Shilhav 2013; Cahaner 2017). As a matter of fact, about a third of the settlers are today members of the ultraorthodox community of the haredim, which has never completely accepted the legitimacy of Zionism but nevertheless gladly reaped the opportunities that the settlement enterprise offers to a demographically exuberant but nonetheless very poor community.

\section{MA'ALE ADUMIM AND THE SUBURBANIZATION OF ISRAEL'S SETTLEMENT POLICY}

In other words, should we have to pick a single case study to investigate Israel's settlement policy, Ma'ale Adumim would serve us much better than Ofra. First, Ma'ale Adumim is in many ways a paradigmatic example of how a large part of the settlements have benefited from their condition of "double centrality" (Newman 1996, 2017) of suburban settlements in Israel territorial development policies: Ma'ale Adumim is located at less than 10 kilometres from the 
Old City of Jerusalem, in an area that is within the economic and geographic centre of the country; at the same time, land prices in the West Bank have been kept at an artificially low level by the government, which has also generously subsidized individuals and companies with financial and fiscal benefits. Large part of the town's 40,000 current residents has moved beyond the Green Line attracted by these benefits, by the high quality of municipal services and by the possibility of commuting to the country's main employment centres. For most residents - and especially for relatively weak and marginalized sectors of Israel's Jewish population, such as second-generation Mizrahi in the 1980s, and immigrants from the former Soviet Union in the 1990s - moving to Ma'ale Adumim has been part of a pattern of upward social mobility which has allowed them to join Israel's middle class.

Second, Ma'ale Adumim is commonly considered as a "consensus settlement," a settlement whose existence is widely regarded as non-controversial by the Israeli public. Since the aftermath of the 1967 war, the idea of building a settlement in the area of Ma'ale Adumim enjoyed the support of a wide and diverse coalition of actors. Before the first nucleus of the settlement was established in the form of a small "workers camp" attached to the industrial area of Mishor Adumim, the Gush Emunim leaders involved in the operation acted essentially as mediators between partisan and non-partisan settlers groups, and key members of the Israeli establishment of the time (Allegra and Handel 2017). A few years later, when the plans for the new town were put forward, it became clear that every sector or group in the Israeli society (apart from the marginal fringe voicing a radical, ideological opposition to the settlements policy) could argue in favour of Ma'ale Adumim: politicians and activists obviously saluted the establishment of a large, fast-growing Jewish community in the periphery of Jerusalem as an appropriate answer to the territorial and demographic challenges inherent to Israel's control on the city; planners and bureaucrats saw it as a rational way to steer urban development and allocate efficiently financial and territorial resources in the face of a growing demographic pressure on the city of Jerusalem; businessmen, developers and real estate agents immediately saw the opportunity for making handsome profits from the construction of 10,000 housing units in a prime real estate area; and, of course, hundreds of families of Jerusalemites who could not afford living in the city rushed to buy new, modern apartments and villas that were on offer at a bargain price (Allegra 2013, 2016). As Thomas Leitersdorf, the head of the Ma'ale Adumim planning team, noted:

"[Ma'ale Adumim] was a success story and every apartment that went on the market was instantly grabbed. So the politicians said, 'Ok, the population in Judea and Samaria is growing, we have no marketing problems and we don't have to pay huge subsidies to support mobile homes on various 
hills' [...]. I would say that the glory of that time was that the planning and political considerations went hand in hand" (quoted in Tamir-Tawil 2003: 155-156).

Third, Ma'ale Adumim shows the profound connection existing between most of the settlements and the social, economic and territorial fabric of Israel. A bedroom community sitting in the eastern periphery of Jerusalem, Ma'ale Adumim is in many ways antithetic to the Wild West that LeBor describes in the West Bank. From the immediate aftermath of the 1967 war, Ma'ale Adumim was considered as a part of the functional area of Jerusalem: it is worth remembering, in this respect, that the first development in the area was not a settlement but rather the industrial park of Mishor Adumim - i.e. an infrastructure designed to cater for a much wider public than the Jewish residents of the West Bank or even Jerusalem. Ma'ale Adumim was therefore planned as a node of a wider metropolitan network centred on Jerusalem, and marketed as a suburb of Jerusalem which offered all the advantages traditionally associated to suburban localities vis à vis the inner city: the latter is defined by overcrowding and chaos, unsustainably high level of real estate prices, poor services, crime and pollution, deteriorating housing stock, and the residents' anonymity; on the contrary, suburbs offer "order/efficiency, daily exposure to nature's beauty and goodness, use of technology to improve the residents' quality of life, aesthetic quality, and the values of individuality, family and community" (Modarres and Kirby 2010: 116). Sarah, who works at the local community centre (the matnas), succinctly captures this set of characteristics when she notes that Ma'ale Adumim "is a great place for kids!" [Sarah, interview] - at the same time indicating the main audience for the city in terms of prospective residents, that is, young couples with children looking for a cheap and secure place to leave at commuting distance from Jerusalem.

The characteristics that set Ma'ale Adumim apart from Ofra and distance it from the stereotypical image of settlements are clearly visible in the experience of the residents. The way Miriam, a retired teacher, recalls her experience as one of the earliest residents of the town is the antithesis of the paradigmatic image of the Zionist pioneer:

"I didn't want to come here... When I came here... there was only the desert, and I was awfully frightened and asked [my husband] 'Why did you bring me here? This is my punishment'... When we came to the lottery [organized to assign the plots]... there were 53 plots in the lottery... I was so happy: number 50 , is not us, number $5 \mathrm{I}$ is not us, number 52 : it was us... I said 'my God!', it was my birthday and the most beautiful gift would have been not to win the lottery" [Miriam, interview]. 
Soon, with the rapid development of the new town, Ma'ale Adumim assumed a very different physiognomy, but the attitude of prospective residents did not change; as a later resident puts it, moving to the town

"was a pretty random kind of decision... We moved here because it was close and convenient and the rent was affordable at the time... We went to a real estate agent, he took us I think... he took us to Gilo [another settlement in the area of Jerusalem, $\mathrm{NdA}$ ], I think he took us to some place in Jerusalem which I've forgotten... It was a question of the rent, and one guy wanted us to pay every three months, one guy wanted us to pay every month. It was a very random" [Daniel, interview].

Rather than idealistic pioneers, the residents of Ma'ale Adumim are white-collar commuters - or, as a real estate ad in the 1980s defined the town's target population, "lovers of Jerusalem" (Thorpe 1984: 119). As Rachel, a gym instructor at the Ma'ale Adumim community centre, remembers,

"[w]e wanted to live close to Jerusalem but not in Jerusalem... I'm a city girl, I grew up in London, I can't live in the middle of nowhere... so we settled in Ma'ale Adumim... it's cheaper [than Jerusalem]... you have the luxury to have a community feeling" [Rachel, interview].

The symbiosis between the suburb and the inner city is so deep that one cannot tell exactly where the former ends and the latter begins - despite the existence of a neat physical gap between the two. Here is what Abigail has to say about her experience as a teenager resident:

"If somebody asks me where I'm from, I'd say Jerusalem, I won't say Ma'ale Adumim. I could say Ma'ale Adumim, it happens, Ma'ale Adumim or Jerusalem it's like the same to me... For instance: everything is in Jerusalem... if you want to go shopping with your parents, you go to Jerusalem... Your parents went to work every day; I went to scouts in Jerusalem... So we came [to Jerusalem] a lot. We went out, we went out in Jerusalem" [Abigail, interview].

\section{A SUBURBAN SAFE SPACE}

The banal and mundane character of Jewish life in the settlements did not create a homogeneous space, uniformly extending "Israel" into the West Bank. It rather contributed to thoroughly reformulate the socio-spatial relations between places and communities in Israel/Palestine - including processes of differentiation and even segregation within the Israeli-Jewish society. 
The first meaningful cleavage emerging from my conversations with the residents, not surprisingly, is one that challenges the idea that "settlers" exist as a homogeneous category simply because they reside beyond the Green Line. It is precisely Ma'ale Adumim's intimate link with Jerusalem (and, by extension, with the Israeli-Jewish mainstream of Israel proper) that marks the difference between the experience of the residents of Ma'ale Adumim and that of the "real settlers." For example, for Abigail the real settlers are those who

"go out and live on a hill, with like caravans, in the middle of nowhere. That's a settler: somebody that lives in this hellhole for no reason [...] [Here in Ma'ale Adumim] there's none of the fanatics... There are degrees of settlers, apparently [laughs]... We're light, light settlers [laughs]" [Abigail, interview].

This distinction, which is fundamentally rooted in the differences in terms of lifestyle, came up again and again in my conversations with the residents, and hardly related to the latter's political background. Daniel (in his own words, an "extreme-right-wing person") spells out his ideological frustration with life in Ma'ale Adumim:

"I feel in many ways ideologically unaccomplished by living in Ma'ale Adumim. If I talk to people from outside Israel, they may see me as a settler... but you probably know already enough about the situation to understand that... it's a kind of a phony settler situation. I am not really a settler in that sense" [Daniel, interview].

Sarah, whose political ideas are opposite to Daniel's, seems to concur as she declares:

"I don't consider myself a settler, I feel I just live in the suburbs... To me lines are invisible... I don't consider myself a settler, I joke around a lot with Rebecca [another resident of Ma'ale Adumim who works for the Israeli nongovernmental organization Rabbis for Human Rights], I say 'you know, we are settlers for human rights" " [Sarah, interview].

The features of Israel's settlement policy that we can recognize in Ma'ale Adumim, however, do not simply create different classes of settlers, but rather are part and parcel of broader patterns of change in the Israeli society. As Lee Cahaner (2017) points out in her study of the ultraorthodox settlers, for example, the creation of large haredi settlements such as Modi'in Illit and Beitar Illit has had far-reaching consequences for the ultraorthodox community. The political orientation of these communities has changed, as the haredim have 
gradually come to embrace the settlement enterprise for a peculiar mix of religious and socio-economic motives, albeit from a particularistic point of view and without adhering to the ideology of mainstream political Zionism. At the same time, the development of large haredi new towns has partly altered the socio-spatial identity of a community whose members rarely ventured outside the traditional ultraorthodox strongholds in Jerusalem and Bnei Brak.

Despite their traditional estrangement from Zionist political discourse, haredim tend to make, so to speak, excellent settlers, due to some of the features of the ultraorthodox society. In part, this is due to structural characteristics of the haredi population, namely its rapid demographic growth (which is translated into hunger for housing) and poverty (which tends to squeeze haredim out of prime real estate locations); in part, this is a result of haredi culture and, specifically, the ultraorthodox instinct for self-segregation. Indeed, Cahaner notes how the development of large haredi settlements, despite the inherent challenges this presented to the community's socio-spatial identity, largely recreated in the West Bank the traditional "wall of holiness" that had protected the haredi way of life by minimizing the contacts with the external world:

"Thanks to their internal cohesion and demographic strength - and, crucially, the provision of publicly funded government services - it has rebuilt its 'walls of holiness' at metropolitan scale. This ensures the development of a coherent ultraorthodox space, with the traditional centres of Bnei Brak and Jerusalem functioning as 'inner cities' of a large and expanding ultraorthodox suburban system. Participation to the settlement enterprise did not open up ultraorthodox space to a more intense exchange with the Israeli-Jewish society as a whole, as might have been predicted; indeed, the 'suburban gated communities' that have been built for the ultraorthodox settlers have reinforced previous patterns of segregation” (Cahaner 2017: 124).

The same dynamic is visible in Ma'ale Adumim: while few of the residents would accept any comparison with their haredi compatriots, the physical, symbolic and socioeconomic gates that set Ma'ale Adumim apart from its surroundings constitute, to some extent, a secular version of the ultraorthodox "wall of holiness." As Oren Yiftachel remarked,

"beyond the powerful impact of the settling ethnocratic culture, there are some influential groups that gain from the establishment of settlements... [U]pwardly mobile groups who seek 'quality of life'... often an euphemism for the rush of middle-class families into gated, or controlled, suburban localities, 'protected' from the proximity of 'undesirables'" (Yiftachel 2003: 36). 
Ma'ale Adumim is not a gated community in a strict sense. In smaller settlements in the West Bank, prospective residents need to apply and pass the screening of local community boards; Ma'ale Adumim's administrative status as a "city" implies that everyone (with the important exception of West Bank Palestinians, who do not have Israeli citizenship) can freely become a resident simply by buying a property on the market. Indeed, on the surface, Ma'ale Adumim - with its 40,000 residents coming from tens of different countries is the poster boy of the Israeli melting pot; still, as it is the case for suburbs all over the world, Ma'ale Adumim is at the same time intimately connected to, and segregated from, its surroundings.

In many ways, the way Ma'ale Adumim functions conforms to Yiftachel's description of settlements - and it represents therefore a "safe space" in which residents are protected from what remains outside the gates. As we have seen, the community constitutes in the first place a shield against the negative externalities that are associated to the environment of the inner city - and that in Jerusalem in particular. Jerusalem is poor, dirty, crowded, and expensive; Ma'ale Adumim, on the contrary, promises prospective residents (traditionally, low- to middle-class young couples with children) a full package of benefits which include superior education for the more than 10,000 students currently enrolled in the local schools, tens of playgrounds and well-kept parks, efficient waste collection, one of the largest community centres in the country, a responsive and generally beloved municipal administration - and a 24-hours security service at the town's four entry gates.

Material benefits such as infrastructure and financial incentives are complemented by a more immaterial component: the quality of life that Ma'ale Adumim guarantees to its residents. A few years ago, the Jewish Agency (the Zionist, para-state organization operating, among other things, in the field of immigrant absorption) offered the following description of Ma'ale Adumim to prospective immigrants:

"[t]he diversity and services of a city, the warmth and quiet of a small town [...] [Ma'ale Adumim] offers a high standard of living, a rich community life, cultural diversity and excellent schools and facilities [...]. Offering the social diversity of the city, [Ma'ale Adumim] nonetheless maintains a camaraderie of neighbourhood connection, synagogue affiliation and a general sense of community involvement" (Jewish Agency's website). ${ }^{1}$

This description found a constant echo in my conversation with the residents, who regularly mentioned the sense of safety, care and belonging as

l From < http://www.jewishagency.org/JewishAgency/English/Aliyah/Absorpton+Options/Municipal + and +Community+Absorption/Maaleh+Adummim.htm $>$, last access in 2012). 
one of the key assets of this thriving community. In a contrapuntal manner, however, the same conversation often touched the issue of "otherness," that is, the existence of groups that, in the eyes of the residents, present a potential challenge to the harmonious functioning of the community.

Palestinians represent the most obvious "exotic other" in the case of Ma'ale Adumim. There are several distinct categories of Jewish-Palestinian encounters in the area of Ma'ale Aduim. First, the Palestinian town of al-Eizariya sits just in front of the southwestern gate of Ma'ale Adumim beyond the traffic circles. Traditionally, the population of Ma'ale Adumim relied on al-Eizariya for a number of services and commercial facilities and even crossed its centre driving to Jerusalem; the first and especially the second Intifada, however - along with the construction of the new road to Jerusalem under Mt. Scopus - brought these interactions to the minimum. Second, many Palestinians work in Ma'ale Adumim as janitors, gardeners, housekeepers, and in the construction sector. Third, a limited number of commercial facilities in the area (primarily the Rami Levy supermarket located in the industrial area, and, to a lesser extent, the mall of Ma'ale Adumim) are used by both communities. ${ }^{2}$

The focus of my conversations with the residents, however, was not so much the actual encounters with Palestinians but rather a mental experiment based on the experience of the settlement of French Hill. French Hill is a neighbourhood in East Jerusalem where a small but growing number of Palestinian families (either Israeli citizens or permanent residents of Jerusalem) have begun to settle in relatively recent times precisely by buying their way in through the local real estate market (Pullan and Yacobi 2017). I therefore asked my respondents how they would react to an inflow of Palestinians in Ma'ale Adumim - would they be surprised by learning that Palestinians live in Ma'ale Adumim? And how would they feel about having Palestinian neighbours? Reactions ranged from mild scepticism to outright refusal to even consider the possibility; the interesting thing, however, were the reasons that were often given to justify the residents' attitude. To be sure, in most cases the residents' arguments have little to do with the history of conflict that has marked Israeli-Palestinian relations in the West Bank in the last 60 years, and with the security threat that is usually associated in Israel to Palestinian presence.

Michael, a US-born computer programmer that moved to Ma'ale Adumim during the 1990s, voiced his scepticism about the appropriateness of Palestinian presence in Ma'ale Adumim by referring to his experience as a resident of New York:

2 Some Palestinians also live in Ma'ale Adumim (I have interviewed one of them), but they are few in numbers, have no communal life in the city. Overall, the scale and the quality of their presence is completely different from cases such as Pisgat Ze'ev or French Hill - two large settlements-neighborhoods in East Jerusalem, see Pullan and Yacobi (2017). 
“The 'why' would be a question mark... I am from New York, the big melting pot, but still you have Chinatown, you have Little Italy... Everyone has their own niche, ok? And that goes for Israel also... You have al-Eizariya and Ma'ale Adumim, you know... Do I see Jews living in al-Eizariya? Probably not. Do I see Arabs living in Ma'ale Adumim? Probably not... I don't know what kind of Arab would want to live in Ma'ale Adumim, [since] the services that he personally may want may not be available for him in Ma'ale Adumim: schooling, religion... I know why I am here, meaning it is a nice Jewish community outside Jerusalem, less expensive than Jerusalem and I love the place. And I moved to Israel to be in a Jewish nation" [Michael, interview].

Clearly, segregation does not require open, violent conflicts to be maintained and even wished for; for Michael it is just part of the human nature, a natural pattern which is in turn reinforced by the presence/absence of infrastructures and facilities that members of specific communities might need or desire. Daniel - a former Londoner who, like Michael, comes from a cosmopolitan urban environment - expressed a similar viewpoint rooted in his personal experience as an observant Jew:

"To be honest, from a social and cultural point of view, there are little relations between the people here and the Arabs... Why?... The truth is that if you would have asked me a similar question when I was living in England, when I was fourteen, the answer would have been pretty similar. I am a religious Jewish person, I don't have much contact with non-Jews, I don't even have much contact with non-religious Jewish people... I lived with non-Jews in the past: it's not something I want but it's not something I would fight. I do believe in people's right to live where they want, as long as they behave" [Daniel, interview].

What is most interesting about these arguments is that they are remarkably detached from the conventional wisdom that see Ma'ale Adumim simply as a settlement built on occupied land in the context of a decades-long conflict; rather, the town represents for its residents a community that caters to an audience of peers, defined by their adhesion to a certain lifestyle. In this respect, the Palestinians represent just one of the potential disruptions of the quiet suburban life that the residents of Ma'ale Adumim have planned for themselves.

It is interesting to relate one of the unexpected results of this mental experiment: when asked about imaginary Palestinian neighbours, my respondents often began talking about another class of difficult "others," namely the ultraorthodox Jews. The haredim, as the Palestinians, are a key part of the 
landscape of the inner city of Jerusalem (where they constitute a third of the city's population) that the residents of Ma'ale Adumim have renounced for the comfort of suburban life. Ultraorthodox communities in Jerusalem live in extreme segregation that is expressed from the spatial standpoint in the existence of "haredi enclaves" such as the neighbourhood of Mea She'arim; have a strict understanding of religious rules regulating, say, Sabbath and women's modesty; and have extremely low rates of participation to the workforce and to the military by virtue of generous subsidies provided by public and private bodies, and of special arrangements with the Israeli state. Because of this, haredi are almost universally despised by secular Jews.

In Ma'ale Adumim haredi presence is limited to the small community of Mizpe Nevo (a neighbourhood appropriately located at the end of a dead-end street in the northern part of the town, which the residents close off on Saturday), whose members are generally described as rather nice people - meaning "not like the haredim in Jerusalem." The spectre of a future haredi invasion, however, seems to loom in the mind of the secular residents as a disturbing scenario. Indeed, I came across (unconfirmed) rumours that the mayor of Ma'ale Adumim has fought off the attempt by a large haredi organization to organize a move en masse to the town, while other residents said that they would leave the town should the presence of religious residents grow above a certain threshold [Adam, interview] or that when they move from Ma'ale Adumim it would be to the Tel Aviv area because of the fast growth of the haredi community in Jerusalem [Hannah, interview].

It is therefore interesting, although not entirely unexpected (also because the perspective of a "Palestinian takeover" of Ma'ale Adumim seems probably more remote than an haredi one), that the comparative judgment passed by most of my respondents on Palestinians and haredim was not generally favourable to the latter, who are seen as a concrete threat to the residents' lifestyle. Hannah, Abigail's mother and a college teacher, declared with no hesitation that she would have Palestinian neighbours rather than haredi:

"Yeah [laughs]! They would probably be nicer people. I'll tell you why: the haredim have an ambition, they want me to be more haredi, the Arabs would not do that, they don't want to convert me, the ones that would come here, they would just live their life" [Hannah, interview].

Voicing some sort of sense of guilt for letting down her fellow Jews, but in an equally unequivocal way, Rachel concurs:

"This is going to sound horrible... Let's say that [a group of haredim] would come to my neighbourhood... To me it would be the same thing [as a group of Arabs]. It would be taking the whole identity and change it. 
The Arab in my neighbourhood would probably not change much of it, but the religious Jew... would insist that I should wear a long skirt..." [Rachel, interview].

It seems that in the opinion of the secular residents of Ma'ale Adumim, Palestinians and haredim share some key cultural traits that distance them from the Israeli-Jewish mainstream; the main difference between the two groups is that, somehow, the haredim inevitably have a collective and political agenda that is advanced through their physical presence in the urban environment, while Palestinians can be considered simply as individuals. Rachel goes on noting that

"[Arabs and haredim] are on the same level and standards: they are both not working; they take money from the social security and services, they both have lots of kids and they are both a drain on society. The haredi side, even if they are supposedly Jewish, they are not on our side... They throw rocks at us, just like the Arabs. If I drive through al-Eizariya I might get stoned, but if I walk through Mea She'arim [an haredi neighbourhood located northwest of the Old City of Jerusalem] like this [indicates her training outfit, $\mathrm{NdA}$ ] I would for sure get stoned" [Rachel, interview].

Beyond the inherent cultural traits of the two groups and their political agenda (or the absence thereof), the residents' assessment on the perspective of neighbourhood relations depends on the socioeconomic status of haredim and Palestinians. And here we can find yet another explanation of the residents' relative preference for the latter: once again, while the Palestinian society as a whole might share some socioeconomic traits with haredi communities, individual Palestinians are different. As Hannah explains,

"Would I be against [the idea of having Arab neighbours like in French Hill]? No... The population that are moving to French Hill have a certain socioeconomic status, they would be doctors, lawyers, etc. It's not the uneducated... That's what I feel; the ones that are upwardly mobile would choose to live in these areas. The ones [who are not] would not think about living here, and they could not afford it in the first place" [Hannah, interview].

\section{CONCLUSION}

The underlying argument of this article is that the success of Israel's settlement policy is due to - and reflected by - the banalization of Jewish presence in the West Bank. The collection of brief flashes about the experience of the 
residents of Ma'ale Adumim sheds some light on two important features of this process of banalization.

In the first place, they make clear that large part of the settlers' population moved to the West Bank for very mundane reasons that had little to do with the tenets of Zionist ideology or grand schemes of socio-spatial engineering. At the same time, banal activities such as moving to the suburbs, commuting to work or obtaining a mortgage have not been less consequential than activists' political campaigns in reshaping the territory of Israel/Palestine. What we have called "Israel/Palestine," and the metropolitan area of Jerusalem that stands at its centre, is in many ways the product of the suburbanization of Israel's settlement policy and of its appeal to almost all sectors and groups that make up the Israeli society; in turn, the suburbanization of Israel's settlement policy cannot be understood without referring to larger trends and processes that have marked the Israeli society starting from the 1970s (such as suburbanization, welfare retrenchment, the dynamics of the real estate market, and so forth).

In the second place, as the formula of "Israel/Palestine" suggests, the settlements have not provided Israel with new borders. Even "consensus settlements" such as Ma'ale Adumim cannot be seen as a prototype of future borders - i. e. territorial artefacts that function (or will function) like the Green Line in the period 1949-1967. The lives of the residents of Ma'ale Adumim are certainly proof that the Green Line does not exist anymore; at the same time, however, while the Green Line functioned as a line of territorial discontinuity, the settlements have created a more porous system by reshaping the interactions between different places and groups - once again, metropolitan Jerusalem being the most obvious and visible case. This transformation has primarily invested Israeli-Palestinian relations, although, one might suspect, not in the linear, straightforward way that conventional wisdom often assumes. This article has tried to show how the same process has had an impact on the Israeli-Jewish society itself, by providing a new socio-spatial context in which the relations between the different groups (secular and religious, low and middle-classes, Mizrahi and Askenazi, etc.) are played out. 


\section{REFERENCES}

ALLEGRA, Marco, 2013, "The politics of suburbia: Israel's settlement policy and the production of space in the metropolitan area of Jerusalem", Environment and Planning A, 45 (3): 497-516.

ALLEGRA, Marco, 2014, "E-1, or how I learned to stop worrying about the two-state solution", Open Democracy, available from < https://www.opendemocracy.net/north-afri ca-west-asia/marco-allegra/el-or-how-i-learned-to-stop-worrying-about-twostate-solu tion $>$ (last access in February 2019).

ALLEGRA, Marco, 2016, "Habanaliyut shel hakibush: hapolitika shel hapirvur beMa'ale Adumim”, Teoria U'vikoret [Theory and Criticism], 47: 45-63.

ALLEGRA, Marco, and Ariel HANDEL, 2017, "Colonizzazione per consenso: la nascita di Ma'ale Adumim (1967-1975) e la politica degli insediamenti israeliana in Cisgiordania", Passato e Presente, 102: 47-67.

ALlEGRA, Marco, Ariel HANDEL, and Erez MAGGOR, 2017, Normalizing Occupation: The Politics of Everyday Life in the West Bank Settlements. Bloomington, IN, Indiana University Press.

ARAN, Gideon, 1991, "Jewish Zionist fundamentalism: the Block of the Faithful in Israel (Gush Emunim)", in Martin E. Marty and R. Scott Appleby (eds.), Fundamentalism Observed. Chicago, University of Chicago Press, 265-344.

BENVENISTI, Eyal, 1989, Legal Dualism: The Absorption of the Occupied Territories into Israel. Boulder, CO, Westview Press.

B'TSELEM, 2018, "Statistics on settlement and settler population", available from < https:// www.btselem.org/settlements/statistics > (last access in February 2019).

CAHANER, Lee, 2017, "Between ghetto-politics and geo-politics: ultra-orthodox settlements in the West Bank”, in Marco Allegra, Ariel Handel and Erez Maggor (eds.), Normalizing Occupation: The Politics of Everyday Life in the West Bank Settlements. Bloomington, IN, Indiana University Press, 112-127.

CAHANER, Lee, and Yosef SHILHAV, 2013, "Ultra-orthodox settlements in Judea and Samaria", Social Issues in Israel, 16: 41-62 [Hebrew].

DALSHEIM, Joyce, 2008, “Twice removed: Mizrahi settlers in Gush Katif”, Social Identities, $14(5): 535-551$.

DALSHEIM, Joyce, and Assaf HAREL, 2009, "Representing settlers", Review of Middle East Studies, 43 (2): 219-238.

ELDAR, Akiva, and Idith ZERTAL, 2007, Lords of the Land: The War over Israel's Settlements in the Occupied Territories, 1967-2007. New York, Nation Books.

FEIGE, Michael, 2009, Settling in the Hearts: Jewish Fundamentalism in the Occupied Territories. Detroit, Wayne State University Press.

FRIEDMAN, Robert I., 1992, Zealots for Zion: Inside Israel's West Bank Settlement Movement. New York, Random House.

GORENBERG, Gershon, 2006, The Accidental Empire: Israel and the Birth of Settlements, 1967-1977. New York, Times Books.

LeBOR, Adam, 2007, "Over the line", New York Times, October $14^{\text {th }}$ (available from $<$ https://ww w.nytimes.com/2007/10/14/books/review/LeBor-t.html >, last access in February 2019).

LUSTICK, Ian, 1988, For the Land and the Lord: Jewish Fundamentalism in Israel. New York, Council on Foreign Relations. 
MODARRES, Ali, and Andrew KIRBY, 2010, “The suburban question: notes for a research program", Cities, 27: 114-121.

NEWMAN, David, 1985, The Impact of Gush Emunim: Politics and Settlement in the West Bank. London, Croom Helm.

NEWMAN, David, 1996, "The territorial politics of exurbanization: reflections on 25 years of Jewish settlement in the West Bank", Israel Affairs, 3 (1): 61-85.

NEWMAN, David, 2017, "Settlement as suburbanization: the banality of colonization", in Marco Allegra, Ariel Handel and Erez Maggor (eds.), Normalizing Occupation: The Politics of Everyday Life in the West Bank Settlements. Bloomington, IN, Indiana University Press, 34-47.

PELED, Yoav, and Gershon SHAFIR, 2002, Being Israeli: The Dynamics of Multiple Citizenship. Cambridge, Cambridge University Press.

PULLAN, Wendy, and Haim YACOBI, 2017, “Jerusalem's colonial space as paradox: Palestinians living in the settlements”, in Marco Allegra, Ariel Handel and Erez Maggor (eds.), Normalizing Occupation: The Politics of Everyday Life in the West Bank Settlements. Bloomington, IN, Indiana University Press, 193-210.

RANTA, Ronald, 2009, The Wasted Decade: Israel's Policies towards the Occupied Territories, 1967-1977. London, University College London, PhD dissertation.

RANTA, Ronald, 2015, Political Decision Making and Non-Decisions: The Case of Israel and the Occupied Territories. Basingstoke, Palgrave Macmillan.

ROKEM, Jonathan, and Marco ALLEGRA, 2016, "Planning in turbulent times: exploring planners' agency in Jerusalem", International Journal of Urban and Regional Research, 40 (3): 640-657.

SHAVIT, Ari, 2013, My Promised Land: The Triumph and Tragedy of Israel. New York, Spiegel and Grau.

SHENHAV, Yehouda, 2012, Beyond the Two-State Solution: A Jewish Political Essay. Hoboken, John Wiley \& Sons.

SPRINZAK, Ehud, 1991, The Ascendance of Israel's Radical Right. Oxford, Oxford University Press.

TAMIR-TAWIL, Eran, 2003, "To start a city from scratch: an interview with architect Thomas M. Leitersdorf", in Rafi Segal and Eyal Weizman (eds.), A Civilian Occupation: The Politics of Israeli Architecture. London, Verso, 15 1-162.

THORPE, Merle, 1984, Prescription for Conflict: Israel's West Bank Settlement Policy. Washington, Foundation for Middle East Peace.

WEISS, Hadas, 2011 , "Immigration and West Bank settlement normalization", Polar: Political and Legal Anthropology Review, 34 (1): 112-130.

YIFTACHEL, Oren, 2003, "Settlements as a reflex action", in Rafi Segal and Eyal Weizman (eds.), A Civilian Occupation: The Politics of Israeli Architecture. London, Verso, 32-39. 